\title{
DISPARITIES IN RURAL DEVELOPMENT OF THE RUSSIAN ARCTIC ZONE REGIONS
}

\author{
Irina Efremova ${ }^{1}$, Nikolay Didenko ${ }^{2}$, Dmitry Rudenko ${ }^{1}$, Djamilia Skripnuk ${ }^{2}$ \\ ${ }^{1}$ Tyumen State University, Russia \\ ${ }^{2}$ Peter the Great St. Petersburg Polytechnic University, Russia \\ i.a.efremova@mail.ru
}

\begin{abstract}
The paper provides the study of specific spatial conditions of rural development of Arctic zone regions in Russia during 2000 - 2015. The aim of the paper is to propose the methodology for rural development disparities study in the Russian Arctic. Spatial development of the Arctic is described by a system of indicators, reflecting the system of the resettlement, the level and quality of life: total population size, life expectancy at birth, housing stock etc. The extent and nature of disparities, particularly, social and economic disparities within the rural territories of the Arctic are explained. The assessment has been based on min-max ratio, coefficient of variation as well as Gini index. Eliminating excessive spatial differences in the social development of urban and rural territories of Arctic regions, improving the demographic situation, raising the level and quality of life of the population should be seen as a priority of the state policy in the Arctic in order to make it attractive for living.
\end{abstract}

Key words: Arctic, disparities, inequality, rural development.

\section{Introduction}

The development of northern territories is considered within two opposite approaches: (1) North as a source of natural resources (a raw appendage of the Russian economy) and a strategic interests zone of Russia, (2) as the territory with extreme conditions of activity where the need to increase the quality of life is a more important task than 'sacrificial work on production of resources for the benefit of regions with favorable climatic conditions' (Artobolevsky et al., 2010). The level and quality of life in northern regions do not correspond to the unique natural resources, advantages of geoeconomic and geopolitical character and do not compensate influence of the extreme climatic conditions. Due to the increasing geopolitical and geo-economic importance of the Arctic, it is necessary to pay special attention to problems of sustainable development of the Russian circumpolar zone, the balanced economic and technical development of the polar regions and to the improvement of inhabitant's well-being.

The negative trends associated with an increase in inter-regional and intra-regional differentiation, with a high degree of social disintegration of population, with a decline in human development are marked in Russia as well as in the Arctic. The Arctic zone of Russia with population of 2.4 million people or just 1.7 percent of the country's total produces about 5 percent of national GDP. Taking it into account the per capita product in all the regions is considerably above the Russia's average. But the quality of life of inhabitants does not correspond to high productivity indicators and does not compensate the severe conditions.

Disparities of spatial development in Arctic regions are shown not only in inequality at the mesolevel, but in deeper distinctions in the regions - between the urban and rural areas. Determinants, scales and consequences of intraregional inequality are studied insufficiently that is explained by the lack of local data. Thus, the main goal of our paper is to reveal the severity of social and economic development problems of urban and rural areas of Arctic regions, to assess spatial development disparities in Russia's Arctic. The paper represents the latest attempt to explore the specific spatial conditions of rural development of Arctic zone regions in Russia. Using a regional-level panel dataset that covers Arctic regions from 2000 to 2015 , we explore the variations in development indicators over time.

\section{Introduction}

The research of territorial distribution features of the cities on the example of France was given in work (Combes et al., 2008), and factors of spatial inequality were revealed. The explanation labor migration with the salary, but also non-market factors (heterogeneity of preferences of placement in space) is reflected by Tabuchi \& Thisse (2001). In later research, Tabuchi, Thisse, \& Zhu (2016) analyzed influence of technological progress in manufacturing and transportation together with migration costs for formation of space. The explanation why skill premia is higher in larger cities, how variation in these premia emerges from symmetric fundamentals, and why skilled workers have higher migration rates than unskilled workers when both are fully mobile is presented in research (Davis \& Dingel, 2012).

Behrens \& Robert-Nikoud $(2013,2014)$ explained the interrelation between the city size, productivity and inequality and found out that income inequality grows with growth of the cities, and the gain in productivity promotes growth of the cities at the expense of incentives to migration from the rural zone in city. Korchak (2016) analyzed the social stability of regions of the North and defined the main priority directions of the public social policy in 
northern regions of Russia. Zubarevich \& Safronov (2013) carried out the analysis of social and economic inequality of regions and cities, using the weighed Gini indexes and coefficient of variation. Features of spatial development of the North and the Arctic are reflected in Artobolevsky et al. (2010); features of development and problem of agricultural industry in the North (an example of the Komi Republic) are reflected in Ivanov et al. (2015). Pilyasov (2009) identified problems of development of the northern periphery, and also a possibility of transition of the North and the Arctic to economy of knowledge that would provide the sustainable development is investigated.

\section{Materials and Methods}

According to the Russian President's Decree \#296 of $2^{\text {nd }}$ of May 2014, the land areas of the Russian Arctic Zone include the territory of the Murmansk Oblast, Nenets Autonomous Okrug, Yamal-Nenets Autonomous Okrug and Chukotka, as well as some municipality territories of the Komi Republic, Republic of Sakha (Yakutia), Krasnoyarsk Krai and Arkhangelsk Oblast. Since the quality of municipal statistics in Russia is very poor, we will compare the regions as a whole.

We have used data for $2000-2015$ published by Federal State Statistics Service, reflecting the system of resettlement, the level and quality of life of the population in rural territories of the Arctic as empirical base of a research:

- total population size is given for resident population covering permanent inhabitants of the given territory, including temporary absentees during the census period. Population comprises urban and rural population according to their place of residence;

- life expectancy at birth, is a mean number of years to be lived by a person from a hypothetical cohort, assuming the mortality level for every age remains the same as in the years for which the rate is calculated;

- housing conditions including the share of the housing stock, equipped with heating, hot water, water disposal;

- education level of able-bodied population - the population having post-graduate professional, higher professional, incomplete higher professional, secondary vocational, primary vocational, secondary (complete) general, basic general, primary general education, and those without education.

The academic literature has suggested a number of different approaches to test the disparities issue, ranging from simple statistical methods (assessment of the dynamics of the standard deviation) to the use of sophisticated econometric models. The cross-regional dispersion of indicators is usually measured by sample variance, min-max ratio, quartile and percentile ratio, coefficient of variation as well as Gini index.

In our analysis, we use coefficient of variation, which is given by:

$$
C V=\sigma / \bar{y} \text {, }
$$

Where $\sigma$ is standard deviation of the proposed indicator and $\bar{y}$ is its mean.

\section{The Rural Development of the Russian Arctic}

The extensive northern territory is characterized by a combination of adverse factors (such as extreme climatic conditions, backwardness and high cost of infrastructure) and unique natural resource and spiritual, and cultural potentials; weak communication of the regional and republican centers with the rural periphery; the low number of large cities which can carry out a role of a link of the general social and economic system; dispersion of residential and rural locations and the centers of industrial activity, their considerable remoteness from each other and from the developed regions of the country; territorial dispersion of a rural population that creates specific living conditions working in branch; backwardness and inaccessibility of transport system; need to use planes and helicopters of small aircraft and hovercrafts; high transport expenses; worn-out fixed business assets; low level of social arrangement; high illness rate (Pilyasov, 2009; Lazhentsev, 2010; Lazhentsev \& Terentyev, 2011; Savelyev \& Titov, 2012; Romashkina, 2015; Simonova, Pogodaeva, \& Zhaparova, 2015; Tarasova, 2015; Nalimov \& Rudenko, 2015).

The dynamics of human development index in Russian Arctic regions over the period from 1999 to 2014 is presented in Figure 1.

Figure 1 indicates that the regional differences have been rapidly decreasing after 2005 due to a weak human development dynamics in the leading Tyumen Oblast and remarkable progress in other Arctic regions during the $2000^{\text {th }}$. The reason for this convergence is the strong redistributive policy (mainly social) and a profound economic growth. Negative character of a demographic situation is a strong barrier of development of Arctic territories. Demographic development in Russian Arctic is characterized by a decrease in total number of the population; reduction of specific weight of a rural population, high mortality rate, migration outflow. Decrease in demographic potential, especially in the rural areas, promotes a sharpening of social and demographic risks of the region that involves problems with reproduction of population and manpower (Bulayev \& Gorina, 2013).

Russia overcame the depopulation phase, which was characterized by high mortality and low birth rates or so called 'Russian cross', only in 2012. The 


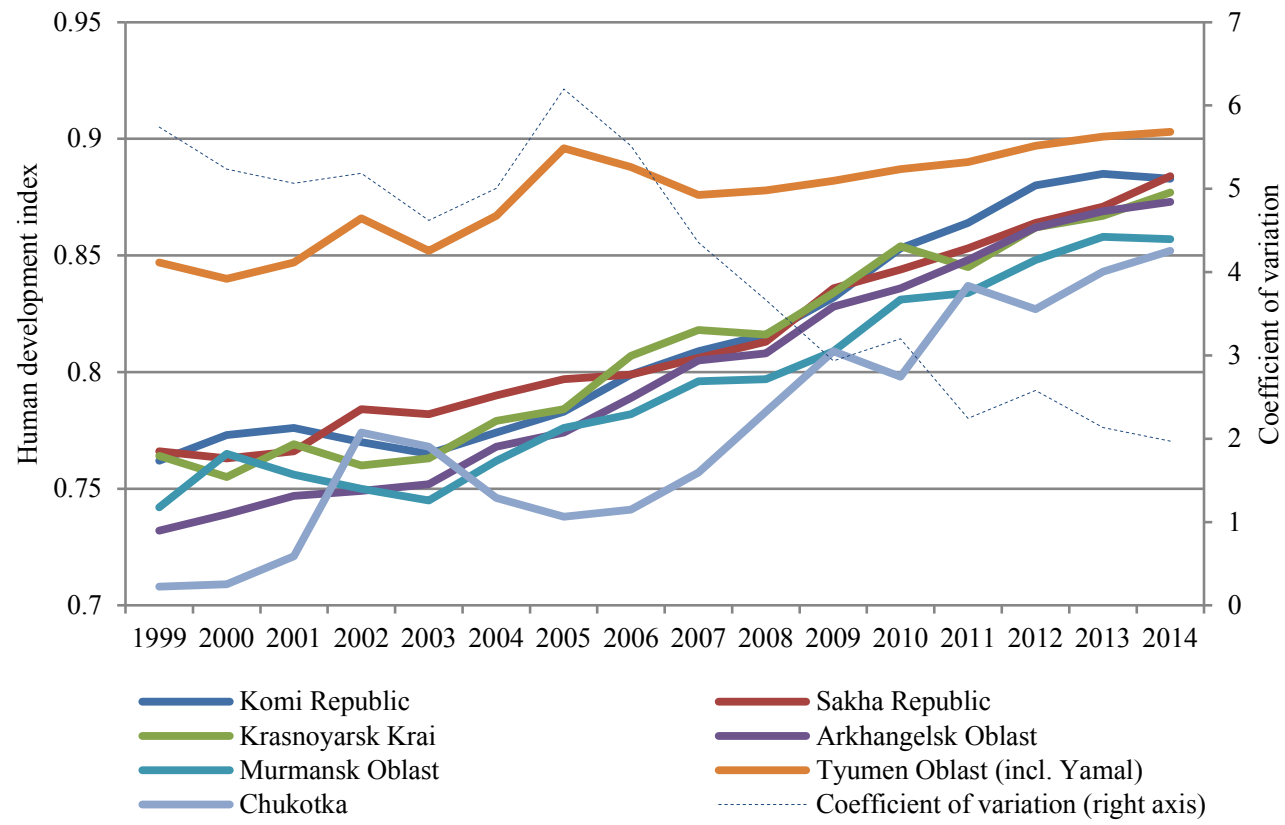

Figure 1. Human development index and its variation in the Russian Arctic zone.

situation in the Russian Arctic remains constant - the population is leaving the Arctic. A slight increase in the number of inhabitants for the last year could be observed only in the most prosperous Nenets and Yamal-Nenets Autonomous Okrugs (Table 1). Russia still has the largest number of Arctic inhabitants, but unlike Canada, the USA and Norway that number is 'melting'.

Negative trends in reproductive processes in the Arctic as well as in Russia sharpened in the 1990s. By the period of 1990 - 1999 the total fertility rate in Russia on average fell from 1.89 to 1.16 . Since 2000 a revival began - the birth rate began to rise. Currently, only in the Murmansk region, the birth rate lags behind the Russian average values. However, the effects of reduced birth rate in the 1990s can be observed right now. First of all, this is expressed in the aging population and the growing shortage of personnel in the economy. The aggravation of the demographic situation in the Arctic was also due to the high level of mortality. The death rate increased from 6.7 per 1000 population in 1990 to 13.4 in 2003 and then gradually began to decline, amounting to 10.4 per 1000 population in 2013. Existing differences in socio-economic, environmental, geographical and other factors of the Arctic regions define different trends in population reproduction processes there. The rate of natural increase and migration increase are the most common characteristics of the intensity of the population reproduction process.

The population of the Russian Arctic regions

Table 1

\begin{tabular}{|l|c|c|c|c|c|c|}
\hline \multirow{2}{*}{\multicolumn{1}{|c|}{ Region }} & \multicolumn{3}{|c|}{ January 2014 } & \multicolumn{3}{c|}{ 1 January 2015} \\
\cline { 2 - 7 } & total & urban & rural & total & urban & rural \\
\hline The Arctic zone of Russia & 2400580 & 2143047 & 257533 & 2391631 & 2135359 & 256272 \\
\hline Komi Republic & 84707 & 84210 & 497 & 82953 & 82481 & 472 \\
\hline Arkhangelsk Oblast & 656624 & 608040 & 48584 & 655100 & 606986 & 48114 \\
\hline Nenets Autonomous Okrug & 43025 & 30478 & 12547 & 43373 & 31118 & 12255 \\
\hline Murmansk Oblast & 771058 & 714445 & 56613 & 766281 & 709548 & 56733 \\
\hline Yamalo-Nenets Autonomous Okrug & 539671 & 452569 & 87102 & 539985 & 452570 & 87415 \\
\hline Krasnoyarsk Krai & 228493 & 205746 & 22747 & 227205 & 204942 & 22263 \\
\hline Sakha Republic & 26447 & 13449 & 12998 & 26194 & 13192 & 13002 \\
\hline Chokotka Autonomous Okrug & 50555 & 34110 & 16445 & 50540 & 34522 & 16018 \\
\hline
\end{tabular}


During the $2000^{\text {th }}$ the situation with the natural increase in the group of Arctic regions was complicated. All regions had positive dynamics of the indicator, which fully corresponds to the national trends. Three autonomous regions and Sakha Republic (Yakutia) have experienced the population increase for the entire period, while on average in Russia a decrease of the population took place. Only in 2013 the crude birth rate exceeded the crude death rate in Russia. The data indicate that the demographic situation in different regions of the new industrial development, such as Yamal-Nenets, Nenets and Chukotka AO, the prevalence of 'young' population structure and high levels of income provide a steady natural increase.

The weakest component of human development in the Arctic is a very low life expectancy at birth. Only one region, Yamalo-Nenets Autonomous Okrug, has managed to increase life expectancy up to 72 years for both sexes. Although it is higher than the Russian average (71 year in 2014 for both sexes), the potential for growth in life expectancy is enormous comparing it with 78 years in Alaska or 75 years in Canadian territories including Yukon, Northwest Territories and Nunavut. Taking into account the hard situation in Chukotka Autonomous Okrug (62.3 years for both sexes), reserves to increase the life expectancy in the Arctic can be evaluated to more than 15 years the break for a whole historical period. Analysis in terms of infant mortality shows the same significant differentiation with the gap between leading Yamal and losing Chukotka being 5 times. The indicator of a life expectancy at birth in rural areas is 5.17 years less than in the urban (Fig. 2 and 3 ) ones.

The very low expectancy of life in Chukotka is explained by the growing suicide rates in the

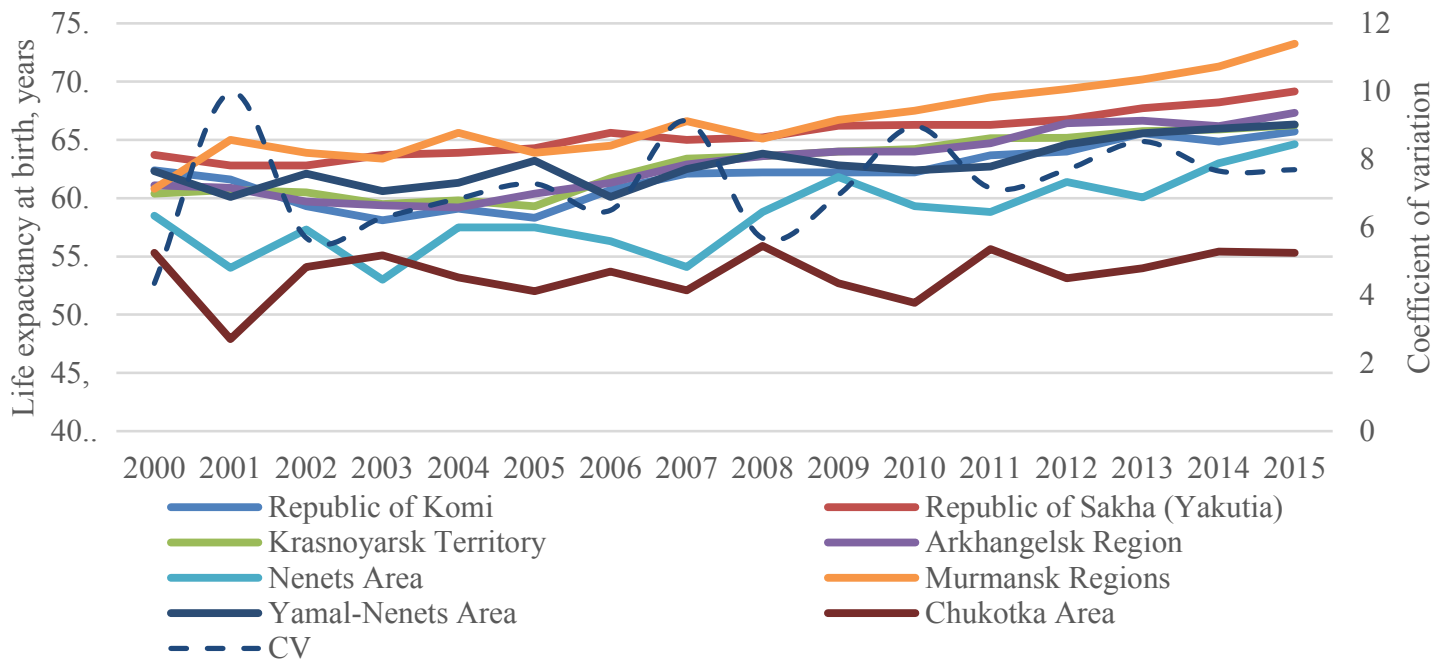

Figure 2. Life expectancy at birth (years) and its variation in the Russian Arctic zone (rural areas).

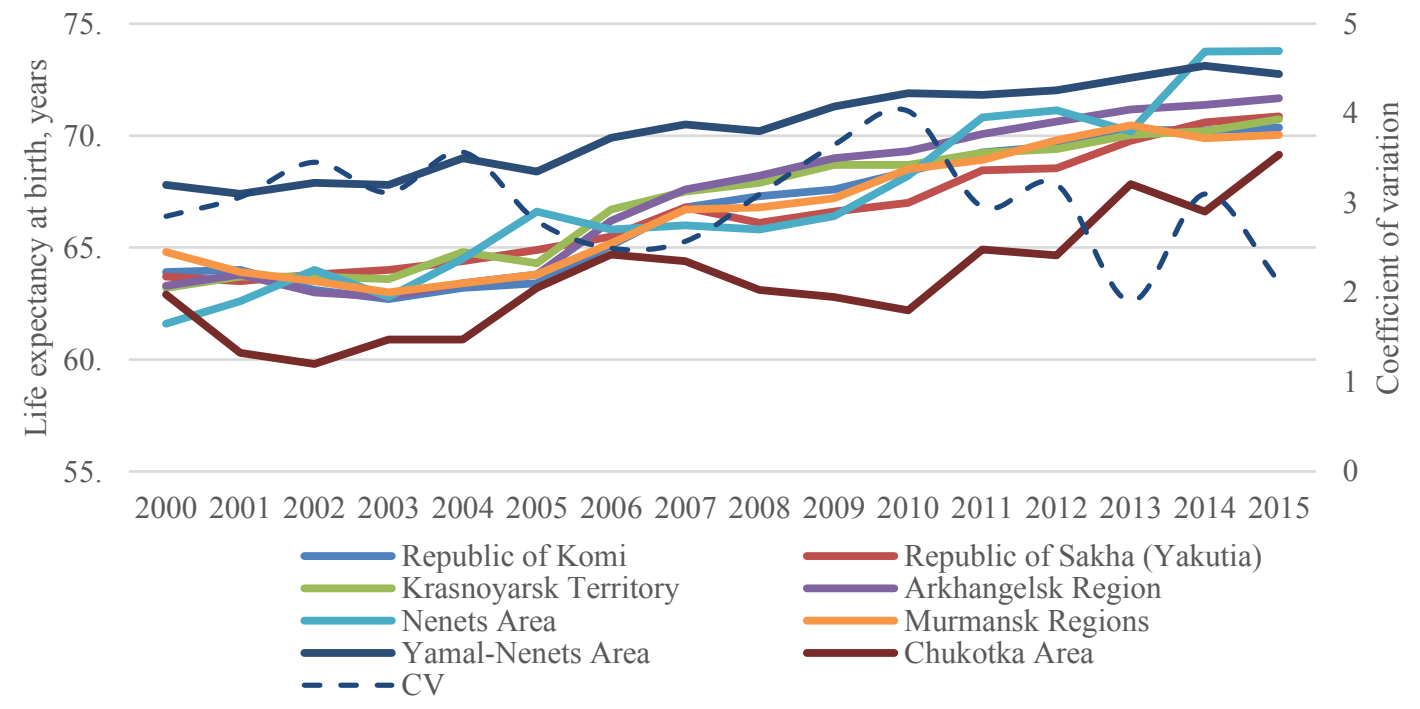

Figure 3. Life expectancy at birth (years) and its variation in the Russian Arctic zone (urban areas). 
region. The problem of suicides especially among the young population of Arctic regions arose several decades ago and reached the peak in the second half of the 1990th.

The lack of access to education or healthcare is also a key factor of well-being (Rudenko \& Didenko, 2016). The Arctic regions as well as all Russian subjects are characterized by imbalanced development of separate components of the human development index. In the majority of northern regions the social infrastructure is characterized by the high level of unevenness of development, low level of availability of services and their limitation, besides, the remote rural areas are in most cases characterized by lack of objects of a social infrastructure. In development of infrastructure the significant gap between rural and urban areas prevails. In the rural areas of Arctic regions, there is insufficiently high level and availability of social services, insufficient security of inhabitants with doctors, average medical personnel, low level of coverage of children with preschool education (in particular indigenous ethnic groups of the North) due to the lack of incentives, and also low transport availability (Toropushina, 2009; Rudenko \& Morosova, 2015). The network of highways with a hard coating averages in the north of 72.1 percent, a gap between maximum (Murmansk region - 94.1 percent) and minimum (Chukotka Autonomous Okrug - 31.4 percent) values of this indicator made 3 times. To compare this area with, other Russian regions, the minimum value of specific weight of roads with a hard coating in the general density of public roads of federal, regional or intermunicipal and local importance constituted 51 percent, in the north of the 2 th region (Republic of Sakha - 40.6 percent, the Chukotka Autonomous Okrug - 31.4 percent) are characterized by values on this indicator below minimum on other regions of Russia.

\section{Conclusions}

An access to health care, opportunities for education and development of skills, the level of comfort of housing remain low in the Russian Arctic. The paradox of human development in resourcerich regions is the lack of infrastructure, high social inequality (in all its forms - money, property, gender, etc.), which leads to lower social well-being of citizens against the background of high incomes.

Thus, regions wholly or partly related to the Arctic zone of the Russian Federation are characterized by the following specifics: complicated demographic situation with high levels of population loss; the extremely low supply of health infrastructure, especially in rural areas; aging of the population; a high mortality rate, as well as an excess of mortality over births; increased alcohol consumption; the lack of qualified personnel; low level provision of housing and social services (health, education, care for the elderly, etc.); weak development of transport infrastructure, especially in the remote and isolated areas.

The study reported here use official up-to-date data from the whole range of Arctic regions of Russia. The empirical results confirm that the Arctic regions are characterized by sharp disparities of qualitative and quantitative social development parameters between urban and rural areas. The policy implications that follow are to eliminate excessive spatial differences in the social development of urban and rural territories of Arctic regions.

\section{Acknowledgements}

The paper is based on research carried out with the financial support of the grant of the Russian Science Foundation (Project No. 14-38-00009, The program-targeted management of the Russian Arctic zone development). Peter the Great St. Petersburg Polytechnic University.

\section{References}

1. Artobolevsky, S., Baranov, S., Barasheva, T., Bashmakova, E., Vasilyev, A., Vinogradova, S., ... Shpak, A. (2010). North and the Arctic in the spatial development of Russia: a scientific and analytical report. Moscow - Apatity - Syktyvkar: Publishing house KSC RAS.

2. Behrens, K., \& Robert-Nicoud, F. (2013). Survival of the Fittest in Cities: Urbanisation and Inequality. Universite de Geneve (WPS 13-07-4).

3. Behrens, K., \& Robert-Nicoud, F. (2014). Agglomeration Theory with Heterogeneous Agents. Universite de Geneve (WPS 14-09-6).

4. Bulayev, V., \& Gorina, K. (2013). Vosproizvodstvennyj potencial gorodskogo i selskogo naseleniya Zabajkalskogo kraya (Reproduction potential of an urban and rural population of Zabaykalsky Krai). Sociologicheskie issledovaniya. 12, 95 - 99. (in Russian).

5. Combes, P.-P., Lafourcade, M., Thisse J.-F., \& Toutain J.-C. (2008). The rise and fall of spatial inequalities in France: A long-run perspective. Paris-Jourdan Sciences Economiques Laboratoire d'Economie Appliquee - INRA (PSE Working Papers n2008-54).

6. Davis, D., \& Dingel, J.I. (2012). A Spatial Knowledge Economy. Cambridge: National Bureau of Economic Research. (NBER Working Paper No. 18188). 
7. Ivanov, V., Lazhentsev, V., Ponomareva, A., \& Terentyev, V. (2013). Razvitie agrarnogo sektora severnogo regiona (Development of the agricultural sector of the Northern Region). EKO. Vserossijskij ekonomicheskij zhurnal. 12, 113 - 129. (in Russian).

8. Korchak, E. (2016). Dinamika socialnoj ustojchivosti i uroven zhizni naseleniya regionov Severa Rossii (Dynamics of social stability and level of living of the population of regions of the North of Russia). EKO. Vserossijskij ekonomicheskij zhurnal. 3, 80 - 95. (in Russian).

9. Lazhentsev, V. (2010). Socialno-ekonomicheskie problemy Severa Rossii (Social and economic problems of Russian North). EKO. Vserossijskij ekonomicheskij zhurnal. 12, 40 - 53. (in Russian).

10. Lazhentsev, V., \& Terentyev, V. (2011). Problemy i prioritety socialnoj politiki ustojchivogo razvitiya selskih territorij (na primere Respubliki Komi) (Problems and priorities of social policy of sustainable development of rural territories (on the example of the Komi Republic)). Ekonomika regiona. 4, 213 - 223. (in Russian).

11. Nalimov, P., \& Rudenko, D. (2015). Socio-economic Problems of the Yamal-Nenets Autonomous Okrug Development. Procedia: Economics and Finance, 24, 543 - 549. DOI: 10.1016/S2212-5671(15)00629-2.

12. Pilyasov, A. (2009). I poslednie stanut pervymi: Severnaya periferiya na puti k ekonomike znaniya (And the last will become the first: The northern periphery on the way to knowledge economy). Moscow: Book House «LIBROKOM». (in Russian).

13. Romashkina, G. (2015). Modernization processes in the regions of Urals federal district. Sotsiologicheskie Issledovaniya. 1, $19-26$.

14. Rudenko, D., \& Didenko, N. (2016). The System of Well-being Indicators in the Russian Arctic Regions. 2nd International Scientific Symposium on Lifelong Wellbeing in the World, 18 - 22 May 2015. European Proceedings of Social and Behavioural Sciences. 7, $514-521$.

15. Rudenko, D., \& Morosova, E. (2015). Prospects for the Development of Further Vocational Education in the Tyumen Region of Russia. Procedia - Social and Behavioral Sciences. 214, 693 - 699.

16. Savelyev, Yu., \& Titov, A. (2012). Novaya model regionalnogo razvitiya rossijskogo Severa (New model of regional growth of the Russian North). EKO. Vserossijskij ekonomicheskij zhurnal. 7, 95 - 101. (in Russian).

17. Simonova, L., Pogodaeva, T., \& Zhaparova, D. (2015). Up The Down Staircase Or How To Improve A Rating. International Conference on Applied Economics (Icoae). 24, 652 - 658.

18. Tabuchi, T., \& Thisse, J-F. (2001). Taste heterogeneity, labor mobility and economic geography. Universite catholique de Louvain, Center for Operations Research and Econometrics (CORE) (CORE Discussion Papers 2001044).

19. Tabuchi, T., Thisse, J-F., \& Zhu, X. (2016). Does Technological Progress Magnify Regional Disparities? Chiba: Institute of Developing Economies (IDE), JETRO (IDE discussion paper № 599).

20. Tarasova, A. (2015). On measurement of modernization stages (by the example of the Tyumen region). Civilization and Modernization, 183 - 187.

21. Toropushina, E. (2009). Socialnaya infrastruktura arkticheskih regionov (Social infrastructure of the Arctic regions). EKO. Vserossijskij ekonomicheskij zhurnal. 8, 120 - 134. (in Russian).

22. Zubarevich, N., \& Safronov, S. (2013). Neravenstvo socialno-ekonomicheskogo razvitiya regionov i gorodov Rossii 2000-h godov: rost ili snizhenie? (Inequality of social and economic development of regions and cities of Russia of the 2000th years: growth or decrease?). Obshchestvennye nauki i sovremennost. 6, 15 - 26. (in Russian). 